\title{
Impacts of Amazonia biomass burning aerosols assessed from short-range weather forecasts
}

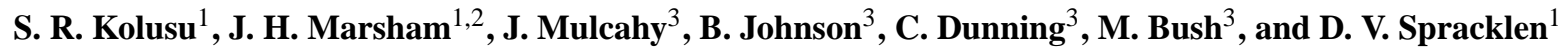 \\ ${ }^{1}$ Institute for Climate and Atmospheric Science, School of Earth and Environment, Leeds, LS2 9JT, UK \\ ${ }^{2}$ National Centre for Atmospheric Science, Leeds, UK \\ ${ }^{3}$ Met Office, FitzRoy Road, Exeter, EX1 3PB, UK \\ Correspondence to: S. R. Kolusu (s.kolusu@leeds.ac.uk)
}

Received: 24 June 2015 - Published in Atmos. Chem. Phys. Discuss.: 10 July 2015

Revised: 26 October 2015 - Accepted: 27 October 2015 - Published: 5 November 2015

\begin{abstract}
The direct radiative impacts of biomass burning aerosols (BBA) on meteorology are investigated using shortrange forecasts from the Met Office Unified Model (MetUM) over South America during the South American Biomass Burning Analysis (SAMBBA). The impacts are evaluated using a set of three simulations: (i) no aerosols, (ii) with monthly mean aerosol climatologies and (iii) with prognostic aerosols modelled using the Coupled Large-scale Aerosol Simulator for Studies In Climate (CLASSIC) scheme. Comparison with observations show that the prognostic CLASSIC scheme provides the best representation of BBA. The impacts of BBA are quantified over central and southern Amazonia from the first and second day of 2-day forecasts during 14 September-3 October 2012. On average, during the first day of the forecast, including prognostic BBA reduces the clear-sky net radiation at the surface by $15 \pm 1 \mathrm{~W} \mathrm{~m}^{-2}$ and reduces net top-of-atmosphere (TOA) radiation by $8 \pm 1 \mathrm{~W} \mathrm{~m}^{-2}$, with a direct atmospheric warming of $7 \pm 1 \mathrm{~W} \mathrm{~m}^{-2}$. BBA-induced reductions in all-sky radiation are smaller in magnitude: $9.0 \pm 1 \mathrm{~W} \mathrm{~m}^{-2}$ at the surface and $4.0 \pm 1 \mathrm{~W} \mathrm{~m}^{-2}$ at TOA. In this modelling study the BBA therefore exert an overall cooling influence on the Earthatmosphere system, although some levels of the atmosphere are directly warmed by the absorption of solar radiation. Due to the reduction of net radiative flux at the surface, the mean $2 \mathrm{~m}$ air temperature is reduced by around $0.1 \pm 0.02^{\circ} \mathrm{C}$. The BBA also cools the boundary layer (BL) but warms air above by around $0.2{ }^{\circ} \mathrm{C}$ due to the absorption of shortwave radiation. The overall impact is to reduce the BL depth by around $19 \pm 8 \mathrm{~m}$. These differences in heating lead to a more anticyclonic circulation at $700 \mathrm{hPa}$, with winds changing by around
\end{abstract}

$0.6 \mathrm{~m} \mathrm{~s}^{-1}$. Inclusion of climatological or prognostic BBA in the MetUM makes a small but significant improvement in forecasts of temperature and relative humidity, but improvements were small compare with model error and the relative increase in forecast skill from the prognostic aerosol simulation over the aerosol climatology was also small. Locally, on a $150 \mathrm{~km}$ scale, changes in precipitation reach around $4 \mathrm{mmday}^{-1}$ due to changes in the location of convection. Over Amazonia, including BBA in the simulation led to fewer rain events that were more intense. This change may be linked to the BBA changing the vertical profile of stability in the lower atmosphere. The localised changes in rainfall tend to average out to give a $5 \%\left(0.06 \mathrm{~mm} \mathrm{day}^{-1}\right)$ decrease in total precipitation over the Amazonian region (except on day 2 with prognostic BBA). The change in water budget from BBA is, however, dominated by decreased evapotranspiration from the reduced net surface fluxes $(0.2$ to $0.3 \mathrm{~mm} \mathrm{day}^{-1}$ ), since this term is larger than the corresponding changes in precipitation and water vapour convergence.

\section{Introduction}

Landscape fires and open biomass burning emit large quantities of trace gases and aerosol to the atmosphere, altering atmospheric composition and impacting weather and climate (Bowman et al., 2009). They are the largest source of carbonaceous aerosols to the atmosphere, contributing $65 \%$ of global total organic carbon (OC) emissions and $25 \%$ of global black carbon (BC) emissions (Lamarque et al., 2010). Moreover, biomass burning contributes to various air 
pollutants that adversely affect human health (Marlier et al., 2013). Biomass burning aerosols (BBA) can significantly alter the energy balance of the atmosphere and the Earth's surface by directly absorbing and scattering solar radiation (Reid et al., 2005) and indirectly changing the cloud properties, thus modulating the hydrological cycle (Ramanathan et al., 2001; Andreae and Rosenfeld, 2008). As a result, BBA affects sensible and latent heat fluxes in the lower atmosphere, altering the temperature of the Earth's surface (Yu et al., 2002; Ichoku et al., 2003). The direct and indirect effects of BBA cause changes in the regional weather and climate via changes in the stability of the atmosphere, height of the boundary layer (BL), regional atmospheric circulation, cloud formation and precipitation (Kaufman and Koren, 2006; Rosenfeld et al., 2008). Despite such impacts on regional weather, most operational weather forecasts only include a climatological treatment of BBA. Here we explore the impact of prognostic BBA on short-term weather forecasts over Amazonia.

The majority of fires worldwide occur in tropical countries (Crutzen and Andreae, 1990; van der Werf et al., 2010) and the tropics play a particularly pivotal role in tropospheric chemistry (Crutzen and Zimmermann, 1991). Landscape fires occur due to both natural and anthropogenic activities, such as forest fires, agricultural crop residue burning, deliberate burning of savannah grasslands and deforestation for agricultural purposes. South America accounts for an estimated $15 \%$ of global fire emissions of carbon from landscape fires and open biomass burning (van der Werf et al., 2010), with regional hotspots of fire activity around the edges of Amazonia. The Amazon region experiences a large number of fires each dry season (August-October). Emissions of BBA from fires greatly increase regional aerosol concentrations (Martin et al., 2010), with dry season aerosol optical depth (AOD) of up to 4 observed at $550 \mathrm{~nm}$ using AERONET sun photometers (Artaxo et al., 2013). Such large concentrations of BBA with large AOD values may have substantial impacts on the regional radiative balance. Procopio et al. (2004) used observations during the dry season to estimate that Amazonian BBA caused a clear-sky radiative effect of -5 to $-12 \mathrm{~W} \mathrm{~m}^{-2}$ at top of atmosphere (TOA) and -21 to $-74 \mathrm{~W} \mathrm{~m}^{-2}$ at the surface. Furthermore, Sena et al. (2013) used a combination of MODIS and CERES data to estimate daily direct TOA radiative effects, which reached $-30 \mathrm{~W} \mathrm{~m}^{-2}$ locally. Rosário et al. (2013) used a regional model to estimate a surface radiative effect of $-55 \mathrm{Wm}^{-2}$. Such changes in fluxes must affect Amazonian weather and a better understanding of this has potential benefits for improving weather and climate prediction.

Modelling studies have explored the impact of BBA on regional weather and climate. Zhang et al. (2008) studied the direct effect of BBA using the regional climate model RegCM3 and found that BBA can weaken regional circulation, cloudiness and perturb land-atmosphere interactions. Zhang et al. (2009) showed that BBA can impact the mon- soon circulation, weakening the South American monsoon circulation by increasing atmospheric stability. Using WRFChem model over South America, Wu et al. (2011) showed that BBA suppressed the diurnal amplitude of convection by about $11 \%$, decreasing clouds (consistent with Cook and Highwood, 2004) and precipitation in the afternoon but increasing them at night. Using the Community Atmosphere Model version 5 (CAM5), Tosca et al. (2013) found that BBA increased global mean AODs by $10 \%$, increased tropospheric heating and decreased global surface temperature by $0.13 \pm 0.01{ }^{\circ} \mathrm{C}$. This resulted in a weakening of the Hadley circulation, causing small reductions in global precipitation but with larger reductions near the Equator.

The South American Biomass Burning Analysis (SAMBBA) was an international project involving groundbased and aircraft observations led by the UK Met Office, the National Institute for Space Research (INPE) Brazil, a consortium of seven UK universities and the University of Sao Paulo. The observational flight campaign was conducted from 14 September to 3 October 2012 across Amazonia. SAMBBA aims to assess the impact of Amazonian BBA on the regional and global radiation budget through the direct, semi-direct and indirect effects, on atmospheric dynamics and the hydrological cycle on numerical weather prediction (NWP) forecasts, on climate and on air quality. In this study we focus on the objective of quantifying the impact of BBA on weather.

Most operational global weather forecast models include a simplified aerosol representation in the form of climatologies. Mulcahy et al. (2014) found that including a more advanced treatment of aerosols and their radiation-cloud interactions improved NWP model biases. SAMBBA provides an ideal opportunity to evaluate the impact of BBA on the meteorology of Amazonia as well as to evaluate the impact of including prognostic BBA coupled to radiation on the forecast model skill. In this study, we present the direct radiative impacts of BBA on short-range weather forecasts using a limited area version of the Met Office Unified Model (MetUM). Cloud-aerosol interactions will be considered in future studies using the MetUM coupled with the more advanced aerosol microphysical model, United Kingdom Chemistry and Aerosol (UKCA). The specific research questions addressed in this study are as follows: (1) what are the impacts of BBA on the mean meteorological state during the SAMBBA period, (2) what are the mechanisms for these impacts and (3) can an improvement in forecast model skill be obtained through use of a fully online BBA model instead of a climatology? To our knowledge, this is the first study which presents the regional-scale interactions and feedbacks using prognostic CLASSIC BBA scheme over South America. The paper is organised as follows: data, model and methods are presented in Sect. 2; Sect. 3 presents results and discussion; finally, the summary and conclusions are presented in Sect. 4. 
(m)

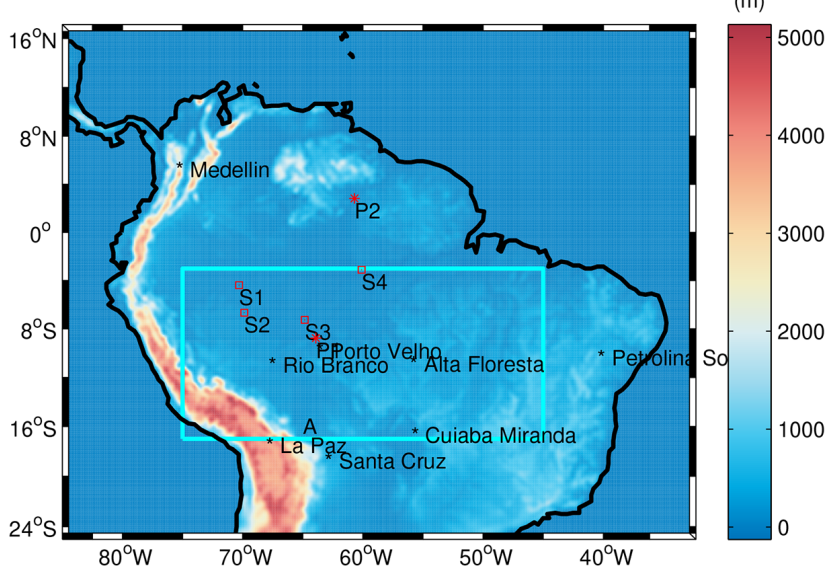

Figure 1. Model domain and orography. Box A (blue) is used to calculate the short-range weather changes due to BBA in Table 2. $\mathrm{S} 1, \mathrm{~S} 2, \mathrm{~S} 3$ and S4 show locations of surface observations at Benjamin Constant, Eirunepe, Labrea and Manaus respectively. P1 and P2 are locations of radiosoundings at Porto Velho and Boa Vista. Asterisks $(*)$ denote AERONET stations.

\section{Model and data}

\subsection{Model}

The MetUM (Davies et al., 2005) is used on a wide range of spatial and temporal scales from high-resolution shortrange NWP to multi-decadal and centennial simulations in an Earth system model configuration (Collins et al., 2011). In this study a limited area model (LAM) configuration of the MetUM is set up over Brazil (Fig. 1) with a horizontal grid spacing of $0.1^{\circ}$ latitude/longitude (around $12 \mathrm{~km}$ ) and 70 levels in the vertical (model lid at $80 \mathrm{~km}$ ). Simulations are run covering the SAMBBA campaign period (14 September to 3 October 2012). Meteorological boundary conditions are provided by the operational global NWP configuration of the MetUM (Global Atmosphere 3.1 configuration; Walters et al., 2011). The atmospheric boundary layer is modelled following Brown et al. (2008) while convection is parameterized using the mass flux scheme based on Gregory and Rowntree (1990). Large-scale precipitation uses the single moment scheme based on Wilson and Ballard (1999), while large-scale cloud is parameterized using the scheme of Smith (1990). Cloud amount is diagnosed as a function of relative humidity by assuming the sub-grid humidity distribution follows a symmetric triangular function centred on the gridbox mean. The width of this distribution is reduced near the surface to account for the reduced variability expected with smaller volume grid boxes on thinner near-surface model levels. The radiation scheme employed is the two-stream radiation code of Edwards and Slingo (1996) with six and nine bands in the shortwave and long-wave parts of the spectrum respectively. The simulations are initialised using a continuous 6-hourly cycle of three-dimensional variational data as-
Table 1. Experimental set-ups using the MetUM model.

\begin{tabular}{ll}
\hline Experiment set-up & Aerosol representation \\
\hline NOA & No aerosol \\
CLIM & $\begin{array}{l}\text { Direct radiative effect (DRE) from } \\
\text { climatological BBA }\end{array}$ \\
PROG & $\begin{array}{l}\text { DRE from CLASSIC BBA prognos- } \\
\text { tic scheme }\end{array}$ \\
\hline
\end{tabular}

similation (3D-Var) (Lorenc et al., 2000) with a 2-day forecast run daily at 00:00 UTC (20:00 (UTC - 4) local time in Porto Velho, Brazil).

Three model experiments, encompassing different representations of aerosols, were conducted to investigate the impact of BBA (Table 1). Firstly, a simulation without any aerosol representation (hereafter termed as NOA) is conducted. Secondly, a set of simulations which include monthly mean speciated aerosol climatologies (hereafter termed as CLIM) is conducted. The climatologies are generated from HadGEM2 climate simulations using the CLASSIC (Coupled Large-scale Aerosol Simulator for Studies In Climate) aerosol scheme (Bellouin et al., 2011). Aerosol species represented include sulphate, mineral dust, biomass burning, OC from fossil fuel, BC from fossil fuel, sea salt and nitrate aerosol. Due to the cost associated with running a fully coupled prognostic aerosol scheme operationally at high spatial resolution, the global operational NWP configuration of the MetUM currently uses these monthly climatologies for all aerosol species apart from mineral dust. Finally, prognostic BBA is included using the BBA component of CLASSIC (hereafter named as PROG). In PROG aerosol climatologies are still used for all other aerosol species, i.e. other than BBA.

A full description of the CLASSIC BBA scheme is given in Bellouin et al. (2011). In PROG, daily BBA emissions are taken from the Global Fire Assimilation System (GFAS) version 1.1 emission data set (Kaiser et al., 2012). These include global emission fluxes from open BB such as deforestation and crop residue burning estimated from satellite-based fire radiative power observations. A number of previous modelling studies have increased BBA emissions by up to a factor of 5 to improve model agreement with observed AOD (Marlier et al., 2013; Ward et al., 2012; Tosca et al., 2013). Here, GFAS emissions were scaled by a factor of 1.7 to give improved agreement of modelled AOD against AERONET observations. The BBA in PROG was spun up from early August and is free running in the forecast. There is no forcing of BBA at the boundaries from the global model, as this does not include prognostic BBA. In all simulations including an aerosol representation, the aerosols are coupled to the radiation scheme (which is called hourly) allowing the direct and semi-direct effect of the aerosols to be simulated. The aerosols do not affect assumed cloud droplet concentrations and so there is no representation of aerosol-cloud 
microphysical interactions, except for wash out of BBA by rain in PROG.

\subsection{Observational data and Methods}

MODIS (Moderate-Resolution Imaging Spectroradiometer) Terra level 3 (King et al., 2003) satellite-retrieved daily AOD at $550 \mathrm{~nm}$, with an uncertainty of \pm 0.05 over land, \pm 0.03 over ocean (Ichoku et al., 2005) and a horizontal resolution of $1^{\circ}$ latitude/longitude are used to evaluate simulated AOD. In addition, we use ground-based retrievals of AOD (level 2) at $550 \mathrm{~nm}$ from eight AERONET stations in the Amazonia region (Holben et al., 1998). ERA-Interim 6-hourly winds and geopotential height at $850 \mathrm{hPa}$ obtained from the European Centre for Medium-Range Weather Forecasting (ECMWF) with a spatial resolution of $1.5^{\circ}$ latitude/longitude (Simmons et al., 2007) have been used to analyse meteorological conditions during the campaign period. For comparison with model simulations we use near-surface temperature and relative humidity observations from different locations over the Amazon region provided by University of Sao Paulo (locations in Fig. 1; data are 6-hourly except for Benjamin Constant, which are 12 hourly) and radiosonde data (12 hourly). The global model is initialised using a continuous 6-hourly cycle of four-dimensional variational data assimilation (4DVar) (Rawlins et al., 2007). But the LAM itself has its own 6-hourly 3D-VAR assimilation (Lorenc et al., 2000) where the $\mathrm{u}, \mathrm{v}$ winds, potential temperature, density, pressure and moisture variables are assimilated on a 6-hourly cycle. In the runs we analyse in this paper, the 2-day $00 \mathrm{Z}$ forecast is spun up from an assimilated start dump and then free running and is forced 3 hourly at the boundaries by the global model forecasts. The impacts of BBA $\left(\Delta_{\mathrm{NOA}}^{\mathrm{BBA}}\right)$ as a function of forecast lead time $t$ can be defined as a difference $\Delta f(t)=f_{\mathrm{BBA}}(t)-f_{\mathrm{NOA}}(t)$, where $f_{\mathrm{NOA}}$ is any meteorological variable in NOA simulation and $f_{\mathrm{BBA}}$ is the same meteorological variable from BBA simulations. In this study, we use the diurnal mean from $t=0$ to $t+24 \mathrm{~h}$ unless otherwise stated. The contribution of other aerosol species to the total aerosol load was small in the Amazonia region during the SAMBBA period.

We have calculated the significant values using the standard error (SE) using the following method; the autocorrelation has been accounted for in the time series of each pixel:

$\mathrm{SE}=\frac{\mathrm{SD}}{\sqrt{N}} k$,

where "SD" is the standard deviation and " $N$ " is the number of points (i.e. how many times contribute to each pixel in the model domain). " $k$ " is the autocorrelation correction factor. This is based on the methodology of Bence (1995):

$k=\sqrt{\frac{(1+p)}{(1-p)}}$, where " $p$ " is the autocorrelation function. " $p$ " is calculated using the Prais-Winsten estimation.

\section{Results and discussion}

\subsection{Meteorological conditions and aerosol distributions during SAMBBA}

ERA-Interim analyses and aerosol loadings from the MetUM are presented in Fig. 2. The data are shown for two distinct periods during the SAMBBA campaign: Period 1 (PD1) from 14 to 22 September and Period 2 (PD2) from 22 September to 3 October 2012. In 2012 there was a transition from the end of the dry season into the wet season around the 22 September (Brito et al., 2014). Periods 1 and 2 therefore had different synoptic conditions and aerosols loadings. Therefore, we analyse results from these two periods separately as well as considering averages from the whole period. Figure $2 \mathrm{a}-\mathrm{c}$ show low-level inflow for each period of air into South America from the east, which turns southwards along the edge of Andes. This inflow is stronger in the second period. Detailed synoptic weather conditions for all the SAMBBA flights are presented in the SAMBBA campaign summary booklet (Darbyshire and Johnson, 2013).

Figure 2 presents the total AOD $(550 \mathrm{~nm})$ from MODIS observations, CLIM and PROG simulations for the whole SAMBBA period, as well as PD1 and PD2. AODs were notably higher during PD1 in both the MODIS data and PROG. This difference is due to BBA, since other species such as sea salt, sulphate and mineral dust make very small contributions over South America during the dry season and the AOD maximum is dominated by BBA. MODIS-retrieved AODs from the SAMBBA biomass burning seasons show large interannual variations with 2012 being a below-average year (not shown). MODIS has a high aerosol loading in the east $(\sim 60$ $50^{\circ} \mathrm{W}$ ) with lower AODs in the west. The CLIM simulation shows large positive bias compared with MODIS particularly in the west of Brazil (around $65^{\circ} \mathrm{W}$ ). As CLIM uses monthly mean aerosol fields it can not capture the reduction in AOD observed in PD2. The PROG simulation is better able to capture the temporal and spatial variability of AOD for all periods. It captures the decrease in AODs in PD2 and the location of the maximum AOD to within $5^{\circ}$. Both PROG and CLIM have too low AOD north of $8^{\circ} \mathrm{S}$, with both models giving too weak local maxima around $8^{\circ} \mathrm{S}$.

Figure 3 compares a time series of the instantaneous observed AOD from AERONET with 6-hourly instantaneous values from the model simulations. PROG is able to simulate the day-to-day variations in AOD at the different AERONET sites, unlike CLIM where any variation in AOD is due solely to changes in the relative humidity. This is demonstrated by positive correlations between AERONET and PROG at all sites except for Medellin (where there are very few data and a single AOD peak is missed, giving a correlation of 
(a. ERA-Interim Whole)

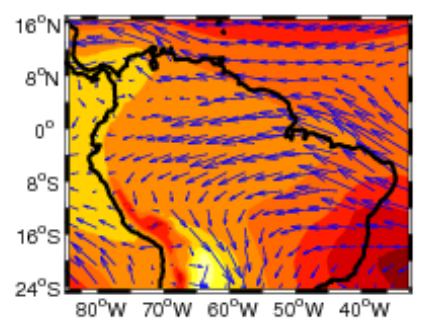

(d. MODIS-AOD Whole)

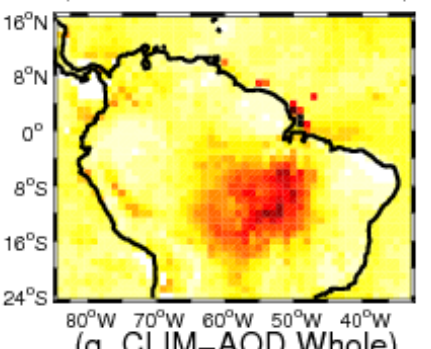

(g. CLIM-AOD Whole)

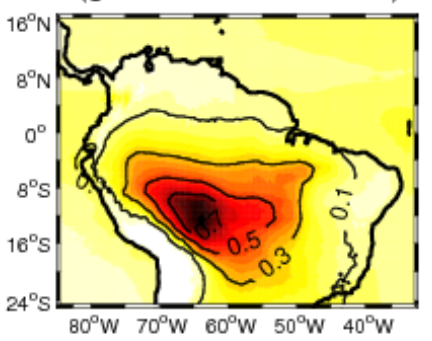

(j. PROG-AOD Whole)

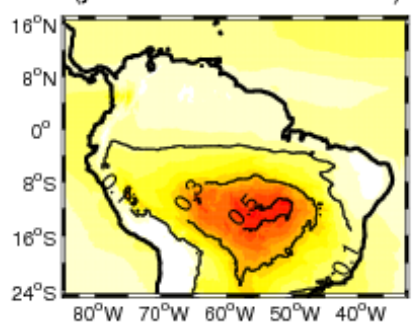

(b. ERA-Interim PD1)

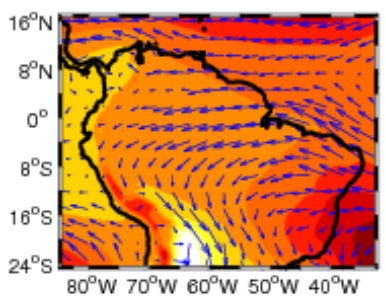

(e. MODIS-AOD PD1)

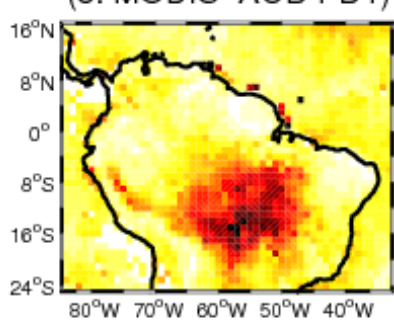

(h. CLIM-AOD PD1)

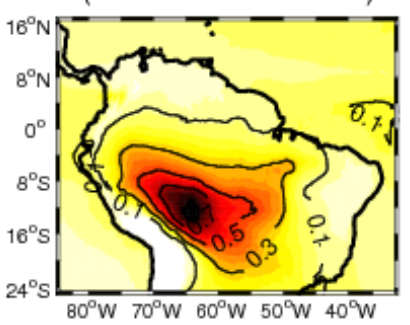

(k. PROG-AOD PD1)

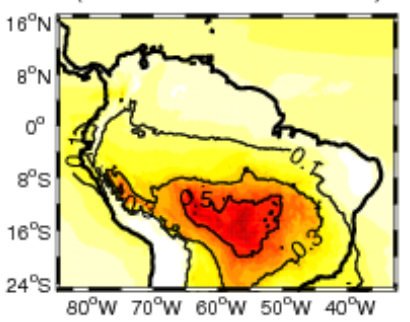

(c. ERA-Interim PD2)

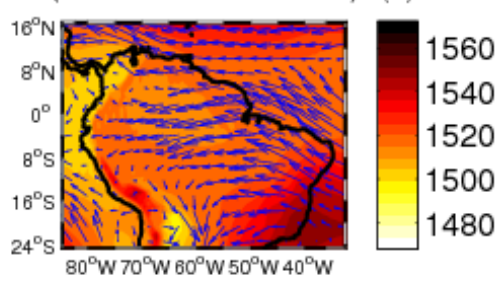

(f. MODIS-AOD PD2)

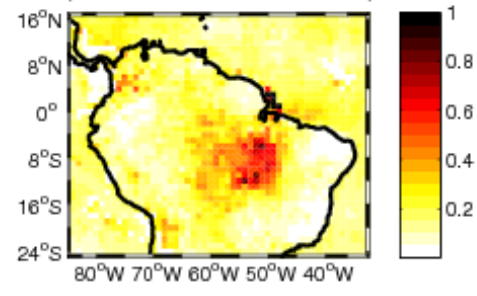

(i. CLIM-AOD PD2)

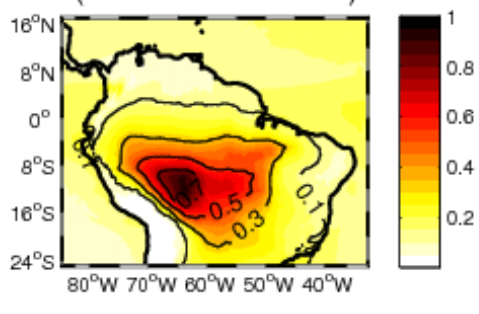

(I. PROG-AOD PD2)

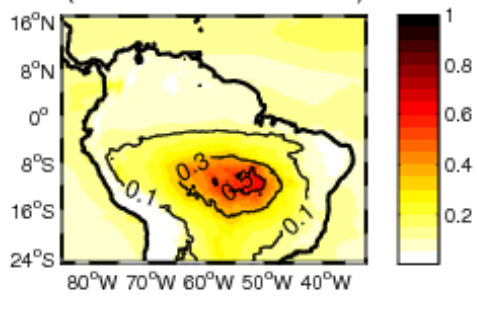

Figure 2. Geopotential height and wind vectors at $850 \mathrm{hPa}$ from ERA-Interim (a, b, c) and $550 \mathrm{~nm}$ AODs from MODIS (d, e, f), from total AOD in CLIM $(\mathbf{g}, \mathbf{h}, \mathbf{i})$ and total AOD in PROG $(\mathbf{j}, \mathbf{k}, \mathbf{l})$. Plots are for whole period $(\mathbf{a}, \mathbf{d}, \mathbf{g}, \mathbf{j})$, first period PD1 (b, e, h, $\mathbf{k})$, second period PD2 (c, f, i, l). Contours show BBA AOD.

-0.1 ). The mean correlation of AOD between AERONET and PROG is 0.4 and is -0.1 for CLIM. However, both PROG and CLIM fail to simulate very high AOD observed at Alta Floresta, Rio Branco and Santa Cruz (Fig. 1), although some discrepancy may arise from comparing a grid-box mean with a point observation from AERONET. Our analysis demonstrates that PROG better captures the observed spatial and temporal variability in BBA over the SAMBBA period.

\subsection{Radiative impacts of BBA}

During both periods of SAMBBA (PD1 and PD2) pattern of impacts of BBA were found to be similar and we therefore focus on the whole SAMBBA period in the remainder of our analysis. Differences in the simulated net radiation fields are calculated relative to NOA for clear-sky conditions at the surface (Fig. 4a and d) and at the TOA (Fig. 4b and e). The net atmospheric divergence (ATM) is calculated as the net radiation at TOA minus net radiation at the surface, giving the change in absorption of radiation in the atmosphere. A summary of the radiative impacts is shown in Table 2, together with their standard deviations, with standard errors in brackets (the standard error will be an underestimate of uncertainty as the data points contributing to the mean are not independent). Values are calculated over the region of box A (shown in Fig. 1) for the whole period for both day 1 and day 2 of the forecast. BBA scatters and absorbs solar radiation reducing 

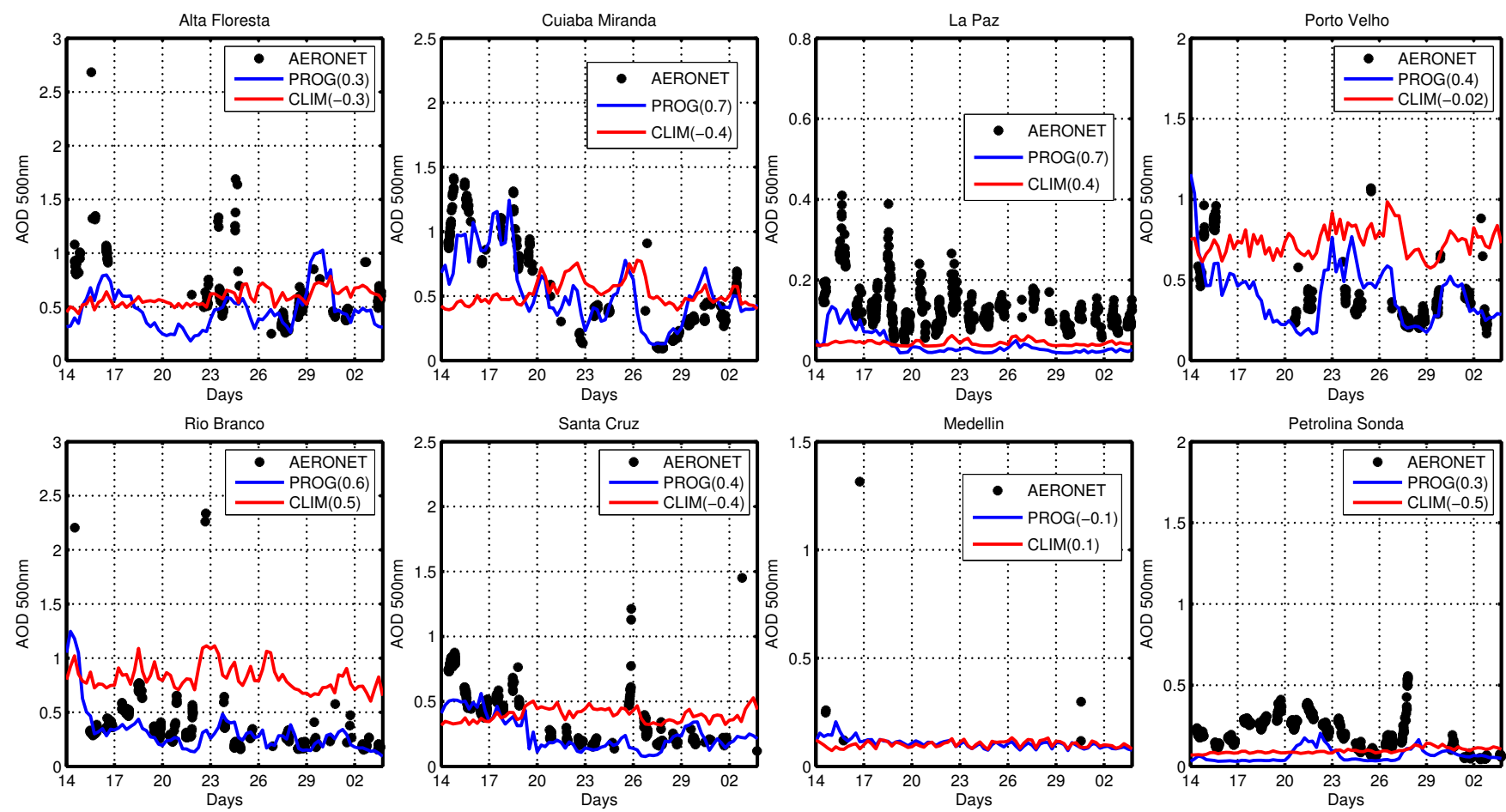

Figure 3. Time series comparison of AERONET (black *), PROG (blue line) and CLIM (red line) $550 \mathrm{~nm}$ AOD at different locations. The correlation coefficients between AERONET and models are shown in parenthesis.

Table 2. Mean modelled short-range weather changes with standard deviations (and standard error in brackets) due to BBA in box A (Fig. 1) over day 1 and day 2 of simulations. The net atmospheric divergence is denoted as ATM. NA denotes that data are not available.

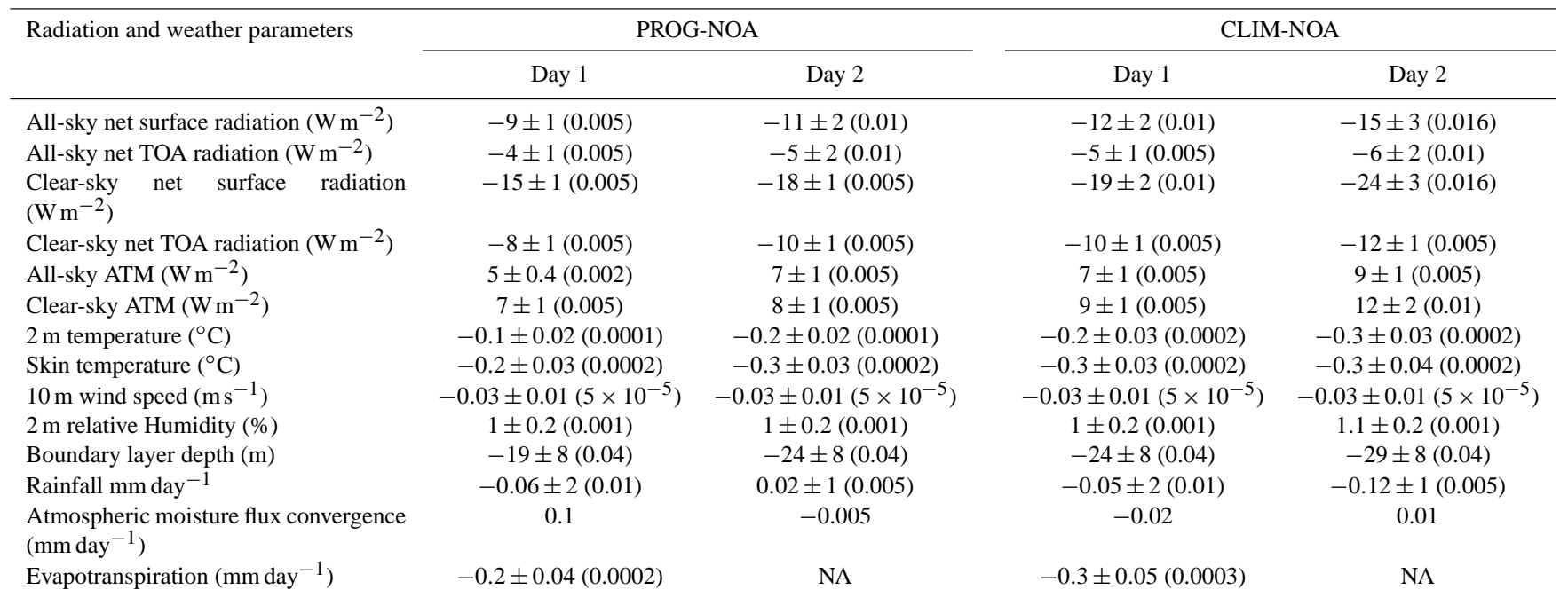

the net surface radiation in CLIM and PROG compared with NOA (see Fig. 4a and d) i.e. the BBA cools the surface. The radiative impacts are larger in magnitude in the CLIM simulation than in the PROG simulation (see Table 2) due to its larger AODs, particularly in western Brazil. In PROG and CLIM the radiative effects are larger on day 2 than the day 1 .
In this model, BBA decreases net clear-sky TOA radiation over Amazonia (Fig. 4b and e). Biomass burning aerosol species in the CLASSIC scheme have a relatively high single scattering albedo (dry value of 0.91 at $550 \mathrm{~nm}$, increasing to 0.95 at $80 \%$ relative humidity) and much of the Amazonian region considered in this study contains forest or vegetated surface with relatively low surface albedos. In a clear sky, the 

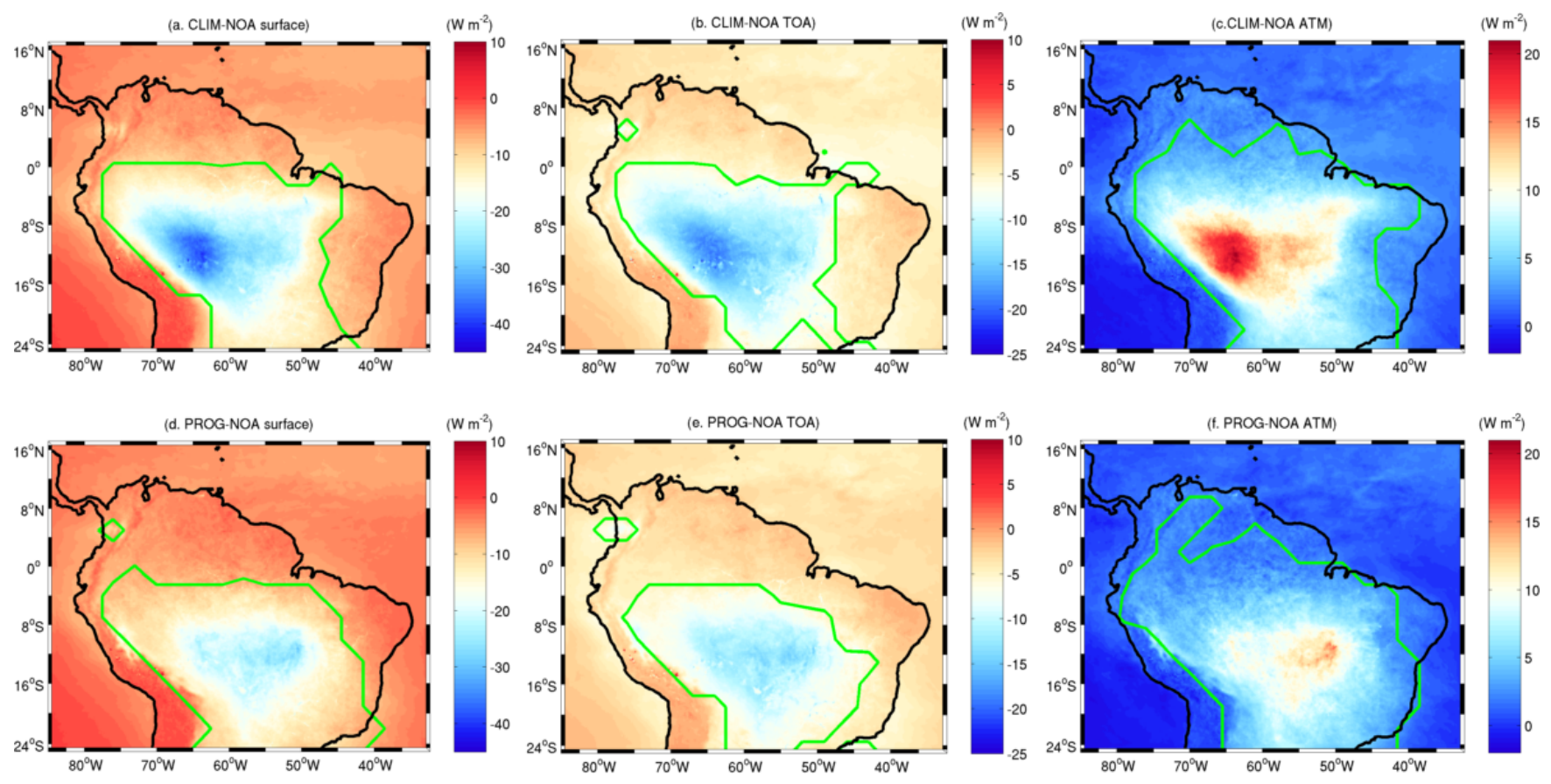

Figure 4. Impact of (top row) CLIM and (bottom row) PROG aerosol representations on (a, d) the net surface radiation, (b, e) net TOA radiation and $(\mathbf{c}, \mathbf{f})$ net atmospheric divergence averaged over the whole SAMBBA period for clear skies. Green contour shows where BBA impacts are greater than the standard error.

impact on net radiation at TOA ranges from 0 to $-25 \mathrm{~W} \mathrm{~m}^{-2}$ for CLIM and 0 to $-15 \mathrm{~W} \mathrm{~m}^{-2}$ for PROG (again with larger impacts found in day 2 in PROG as well as in CLIM, Table 2). The negative change in net TOA radiation (consistent with Haywood and Boucher, 2000; Procopio et al., 2004; Sena et al., 2013) does not agree with results from Ten Hoeve et al. (2012) which showed a positive change for higher AODs (i.e. Earth-atmosphere warming) and included both direct and indirect aerosols impacts, and the magnitude of the change in surface radiation is consistent with other studies (Procopio et al., 2004; Kaufman and Koren, 2006; Rosenfeld et al., 2008; Sena et al., 2013). The increase in radiative absorption across the atmosphere (ATM) is between 10 and $20 \mathrm{~W} \mathrm{~m}^{-2}$ (slightly greater in CLIM than PROG due to greater AODs) (Fig. $4 \mathrm{c}$ and $\mathrm{f}$ ). The radiative absorption range by aerosols in the atmosphere found for the whole period is in good agreement with the value of $18.7 \mathrm{~W} \mathrm{~m}^{-2}$ found in a case study from the same period using the WRF-Chem model (which includes prognostic BBA with both direct and indirect effects from Archer-Nicholls et al., 2015).

More subtle impacts on model cloud fields are found in PROG and CLIM on horizontal scales of $1^{\circ}$ and a systematic decrease in high and medium cloud fraction of around 0.1 is found in areas of highest AODs (cloud changes are described later in Sect. 3.3). This may be a result of BBA stabilising the atmosphere, as discussed in Sects. 1 and 3.3. Changes in allsky net radiation, which include the impacts of changes in the cloud fields resulting from BBA's direct effects, are lower in magnitude by around a factor of two compared with clearsky values (Table 2), but the overall patterns are similar (not shown), i.e. the reduced cloud in PROG and CLIM compared with NOA decreases the magnitude of the surface and TOA cooling induced by the BBA.

\subsection{Impacts of BBA on atmospheric thermodynamics}

Over the whole SAMBBA period, the decrease in net surface radiation from $\mathrm{BBA}$ decreases the mean $2 \mathrm{~m}$ air temperatures by up to $1.4^{\circ} \mathrm{C}$, but with local increases of up to about $0.5^{\circ} \mathrm{C}$ due to changes in cloud (Fig. 5). In PROG, the mean impact over Box A is a $0.1^{\circ} \mathrm{C}$ decrease on day 1 , reaching $0.2^{\circ} \mathrm{C}$ decrease on day 2 (Table 2; effect is $0.03^{\circ} \mathrm{C}$ larger in CLIM). The largest changes are found, as expected, close to regions of maximum BBA. The differences are largely restricted to the land, where air temperatures respond to the modelled surface energy balance. Tosca et al. (2010) showed that BBA can affect SSTs (Sea Surface Temperatures) around Indonesia, but in all simulations here the SSTs are prescribed from reanalysis. Over land, the BBA cools the surface skin temperature by approximately $0.2^{\circ} \mathrm{C}$ on day 1 and $0.3^{\circ} \mathrm{C}$ on day 2 . Over Box A $10 \mathrm{~m}$ wind speeds are reduced (Table 2), likely due to decreased surface sensible heat fluxes reducing downward mixing of momentum to the surface.

The impacts of BBA on atmospheric radiative and surface heating rates affects the thermodynamic structure of the atmosphere far above the surface. Figure 6a shows potential 

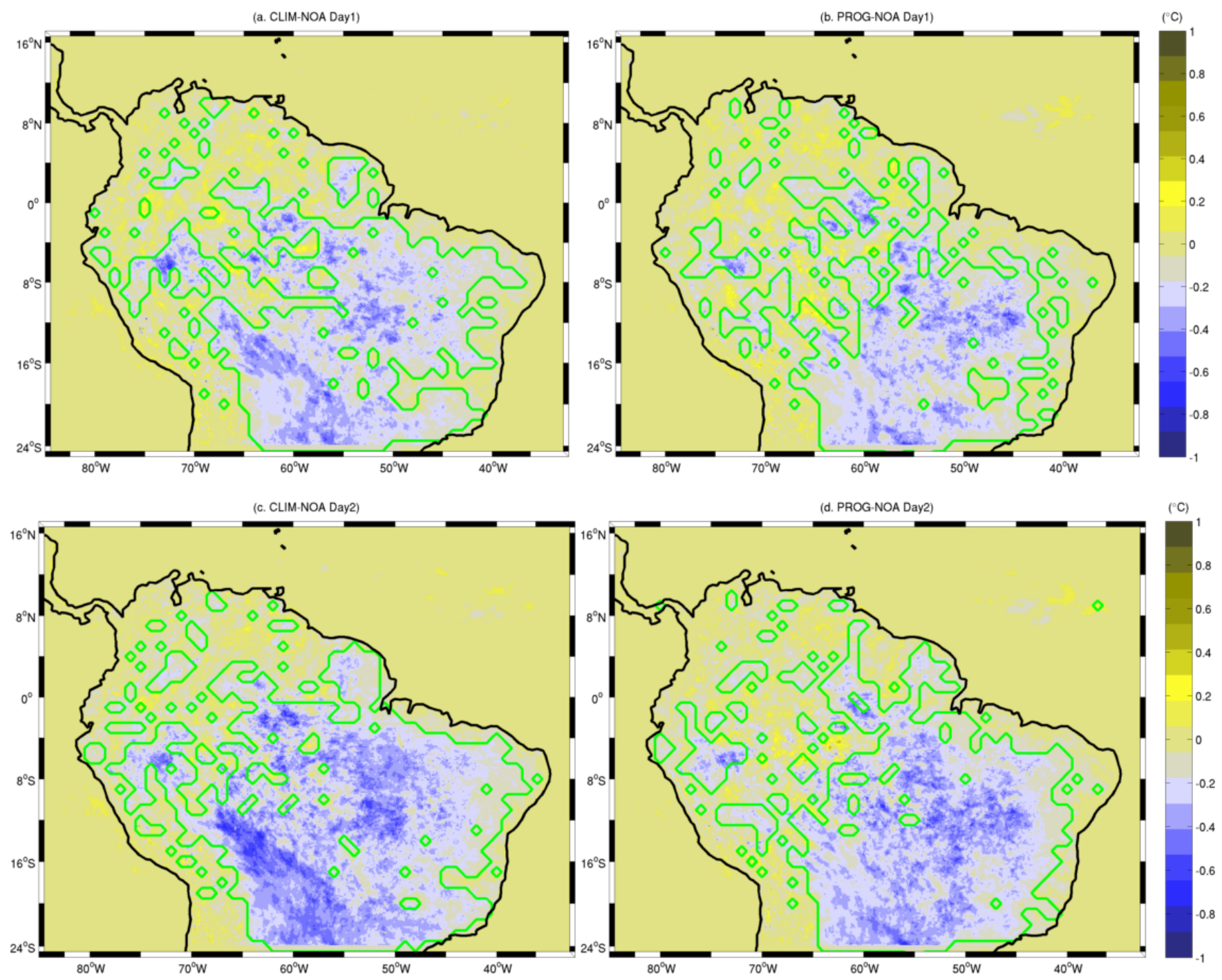

Figure 5. Impact of BBA on $2 \mathrm{~m}$ air temperature for day $1(\mathbf{a}, \mathbf{b})$ and day $2(\mathbf{c}, \mathbf{d})$. Green contour shows where BBA impacts are greater than the standard error.
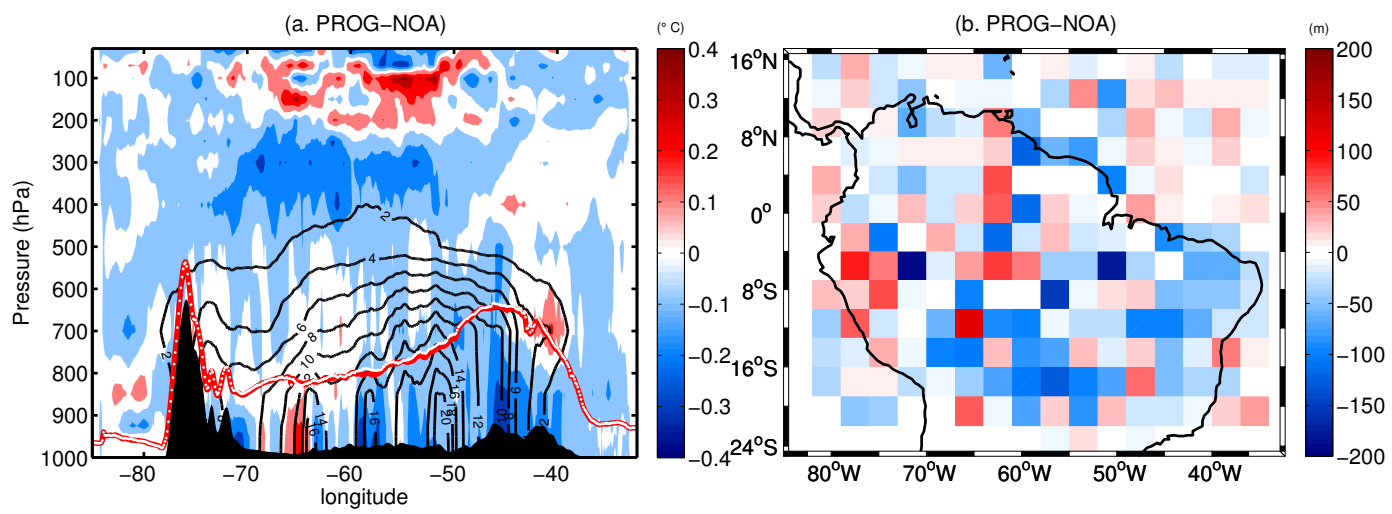

Figure 6. (a) Differences in potential temperature (coloured) and BBA mass mixing ratio (ng $\mathrm{g}^{-1}$, black contours) averaged over $10-13^{\circ} \mathrm{S}$ for the entire campaign period at 18:00 UTC for PROG-NOA. Red and white lines are boundary layer depth of PROG and NOA respectively. Topography is masked black. (b) Differences in BL height PROG-NOA. 
temperature cross sections averaged over the 10 to $13^{\circ} \mathrm{S}$ latitude belt, chosen as it is the region where surface impacts of BBA are largest in Figs. 4 and 5. Figure $6 \mathrm{a}$ and $\mathrm{b}$ are plotted for 18:00 UTC (14:00 local time) in order to show a welldeveloped afternoon BL, with BL depth shown for NOA (white line) and PROG (red line). BBA mass concentrations (contoured) are well mixed within the BL and extend higher in the east where the BL is deeper (around $400 \mathrm{hPa}$, compared with $500 \mathrm{hPa}$ in the west). Figure 6a shows that BBA cools the lower atmosphere over land (blue colours in Fig. 6a), consistent with the reduced net surface radiation. This cooling is deeper in the east where the BL is deeper (reaching around $700 \mathrm{hPa}$ ). BBA warms the atmosphere above this (red colours in Fig. 6a) with this warming centred around the top of the BL or just above it. This warming is consistent with the direct radiative effects of the $\mathrm{BBA}$, extending higher in the east where the BBA extends higher. The reduced net surface radiation from BBA reduces surface fluxes and this, combined with the increased atmospheric heating from BBA, reduces entrainment into the $\mathrm{BL}$, and so $\mathrm{BL}$ depth reduces by up to $150 \mathrm{~m}$ (Fig. 6b) with a daily mean impact of $19 \mathrm{~m}$ over Box A (Table 2). Differences in BL height in Fig. 6b are not statistically significant but are consistent with radiative flux changes.

Figure 6 shows that the effects of BBA on temperatures above the surface layer are between -0.2 and $+0.2^{\circ} \mathrm{C}$ when averaged over the entire SAMBBA period $\left(\sim \pm 0.4{ }^{\circ} \mathrm{C}\right.$ in the first sub-period, with similar patterns, not shown). The effect of the BBA on temperature extend well above the BBA, with effects between 100 and $400 \mathrm{hPa}$ as large as those lower in the atmosphere. Overall, there is a weak cooling at the surface and above the aerosol layer at $500 \mathrm{hPa}$ and warming at $150 \mathrm{hPa}$ (corresponding to approximately $15 \mathrm{~km}$ altitude). These changes are consistent with Chen et al. (2014) who simulated radiative effects during a wild fire event over the United States using the WRF-Chem model. These are also consistent with changes in vertical motion induced by the BBA, as discussed below.

Cross sections of relative humidity $(\mathrm{RH})$, ice cloud water (QCF) and liquid cloud water (QCL) are presented in Fig. 7 at 18:00 UTC in a similar manner to Fig. 6 a for potential temperature. Differences in the RH profiles are consistent with changes in the potential temperature profile within the BL. BBA tends to decrease RH above the BL (Fig. 7a), consistent with the warming induced there (Fig. 6a), although differences in the patterns shown in Figs. 6a and 7 show that changes in water vapour mixing ratio are also important for $\mathrm{RH}$. Consistent with the decrease in RH from BBA above the BL, BBA decreases both QCF and QCL (Fig. 7b, and c); i.e. BBA suppresses middle- and high-level clouds, consistent with aerosol semi-direct effects from other studies (Jacobson, 2002; Korontzi et al., 2004; Wu et al., 2011; Chen et al., 2014).

Figure 8a shows changes in geopotential and horizontal and vertical winds for the same cross section as Fig. 6a. The surface cooling with heating above, induced by the BBA, which has a vertical extent that depends on the BL depth and height of the BBA and an intensity that depends on the BBA loading, induces a weak surface high pressure around $50^{\circ} \mathrm{W}$ and a weak low pressure at $65^{\circ} \mathrm{W}$ (Fig. 8a). Low-level wind changes are consistent with this but only reach $0.5 \mathrm{~m} \mathrm{~s}^{-1}$. The effects are stronger at $700 \mathrm{hPa}$, where the horizontal gradient in $\mathrm{BL}$ depth and BBA heating gives a low pressure relative to $\mathrm{NOA}$ at around $50^{\circ} \mathrm{W}$ and a relative high pressure at $65^{\circ} \mathrm{W}$. This gives a weak anti-cyclonic circulation at this level in the runs with BBA compared with NOA (Fig. 8b), with differences in winds reaching $0.6 \mathrm{~m} \mathrm{~s}^{-1}$.

Changes in winds above $400 \mathrm{hPa}$ are again consistent with the changes in geopotential there and are larger than below due to the strong winds at this level in the atmosphere. Figure 8 a shows that BBA generates ascent and so cooling centred at around $350 \mathrm{hPa}$ and $65^{\circ} \mathrm{W}$ and descent above, consistent with the cooling and warming shown at these levels in Fig. 6a. Small changes in vertical winds (Fig. 8a white lines) cause relatively large changes in temperature at these heights in the atmosphere, which are very stable. The fact that the temperature changes at these levels are consistent with vertical motion induced by BBA suggests an upper-level wave response to the direct effects and heating from the BBA below. Similar patterns are found in the CLIM but the impacts are larger where the AOD is higher.

\subsection{Evaluation of BBA impacts on the short-range forecasts}

The majority of regional and global operational NWP models currently use a climatological representation of aerosols. Here the impact of BBA on the NWP forecast skill is evaluated in order to ascertain whether a more advanced treatment of aerosols leads to an improvement in model predictions. Figure 9 shows the mean bias and root mean square (RMS) error in modelled $2 \mathrm{~m}$ temperatures as a function of forecast lead time at the four sites shown in Fig. 1 averaged over the whole period. The inclusion of aerosols tends to improve the surface temperatures biases in forecasts, but improvements are small compared with mean bias and RMS error. Mean correlations between observations (S1 to S4 locations in Fig. 1) and modelled values are significant and are always higher for PROG or CLIM than NOA (e.g. for temperature (relative humidity), 0.83 (0.79) for PROG and 0.82 (0.77) for CLIM compared with 0.79 (0.72) for NOA). This difference between PROG or CLIM and NOA is significant at the $85 \%$ level (Hoerger, 2013) and shows that including BBA leads to a small improvement in $2 \mathrm{~m}$ temperature. Differences between CLIM and PROG are not significant and it is clear from Fig. 9 that including a fully prognostic BBA scheme does not lead to a significant improvement in skill relative to CLIM, although more observations from the west of the domain where aerosol fields of PROG and CLIM show 

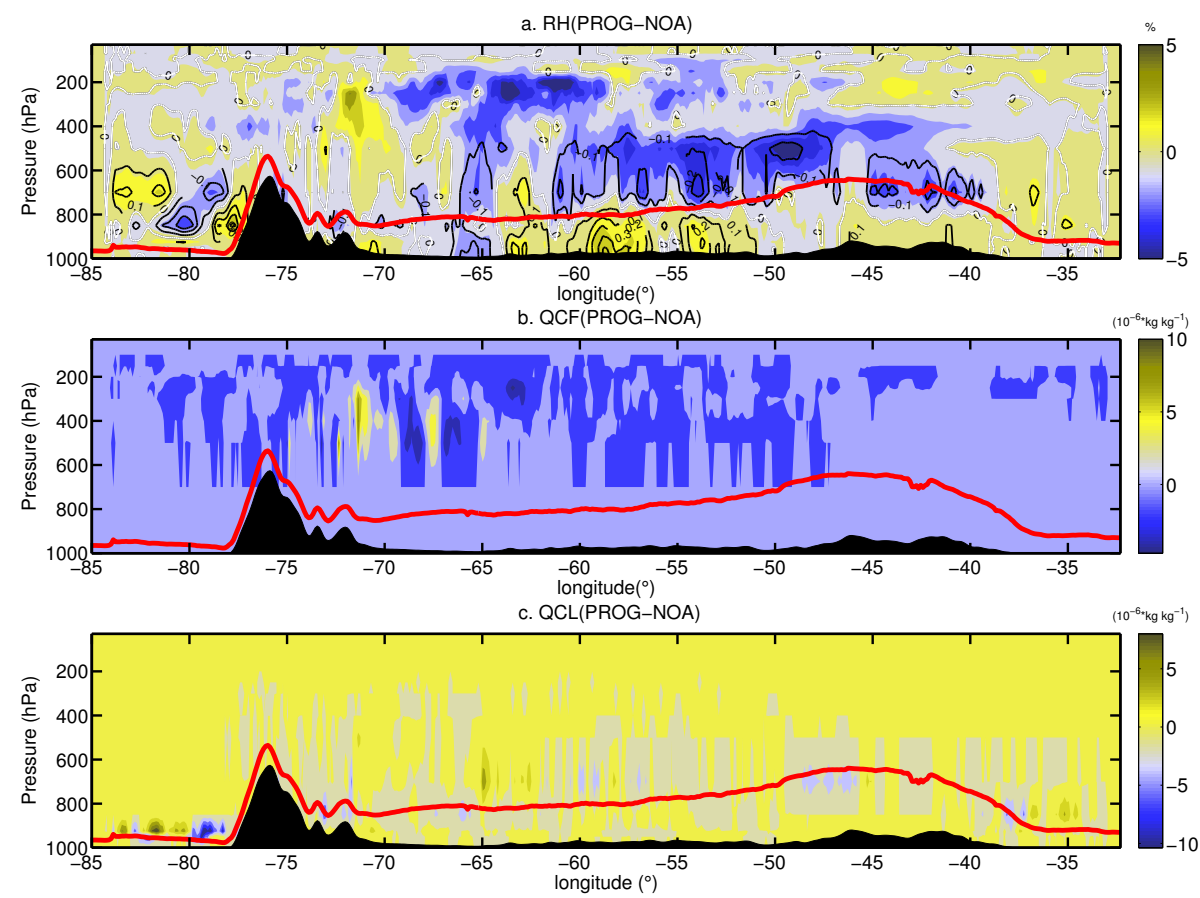

Figure 7. As in Fig. 6 but differences are for (a) relative humidity (coloured), black contours are specific humidity ( $\left.\mathrm{g} \mathrm{kg}^{-1}\right)$, (b) ice cloud water (QCF) and (c) liquid cloud water (QCL). The red line is boundary layer depth of PROG. Topography is masked in black.
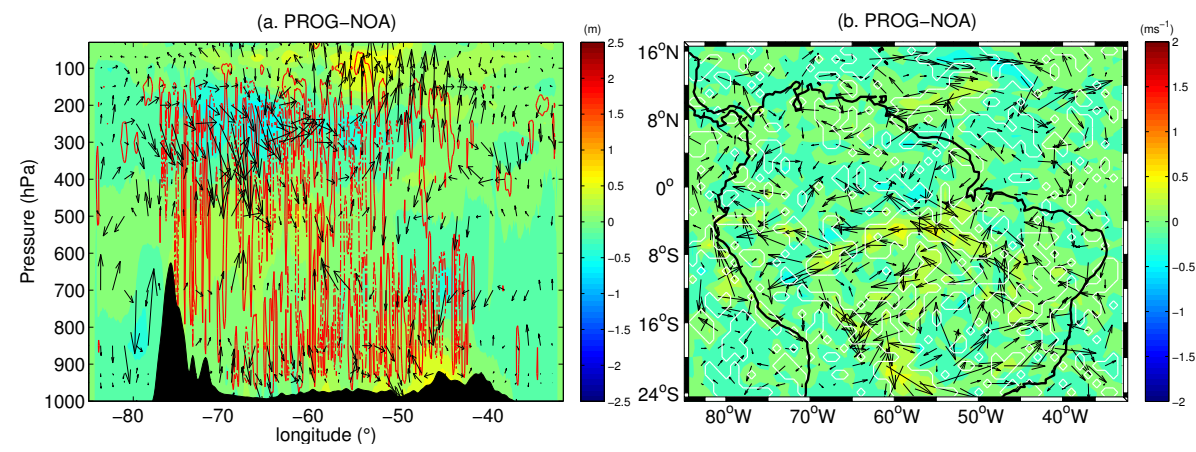

Figure 8. (a) Differences in geopotential height (coloured) and $u, v$ winds (arrows) averaged over $10-13^{\circ} \mathrm{S}$ for the $\mathrm{SAMBBA}$ whole period for PROG-NOA; red contours show differences in vertical wind (dashed lines show negative values and solid lines positive values). Black masked area is the topography. (b) Circulation and wind speed changes at $700 \mathrm{hPa}$ for PROG-NOA. White contour shows where BBA impacts are greater than the standard error.

greater differences might reveal more benefits of PROG compared with CLIM.

Figure 10 presents the mean bias in simulated temperature and relative humidity profiles at Porto Velho and Boa Vista for the entire SAMBBA period compared to radiosondes at 00:00 and 12:00 UTC. Mean temperature errors are less than $1^{\circ} \mathrm{C}$ above $850 \mathrm{hPa}$ but reach $5^{\circ} \mathrm{C}$ at the surface in Porto Velho. Relative humidity errors reach $\pm 20 \%$ and are again largest closest to the surface. These large biases at 00:00 UTC in the model near the surface are due to the model failing to accurately capture the nocturnal stable layer, a common problem in regional NWP models. For temperature and humidity, differences between the aerosol simulations are generally small apart from at Boa Vista where PROG leads to an increase in relative humidity above $850 \mathrm{hPa}$. The model biases in temperature will affect vertical mixing of aerosol, but we do not anticipate that they substantially affect modelled sensitivities to BBA.

\subsection{Impacts of BBA on precipitation and the water budget}

Although the simulations conducted in this study do not couple the BBA with cloud microphysical processes, the BBA can alter precipitation as direct radiative effects have an 

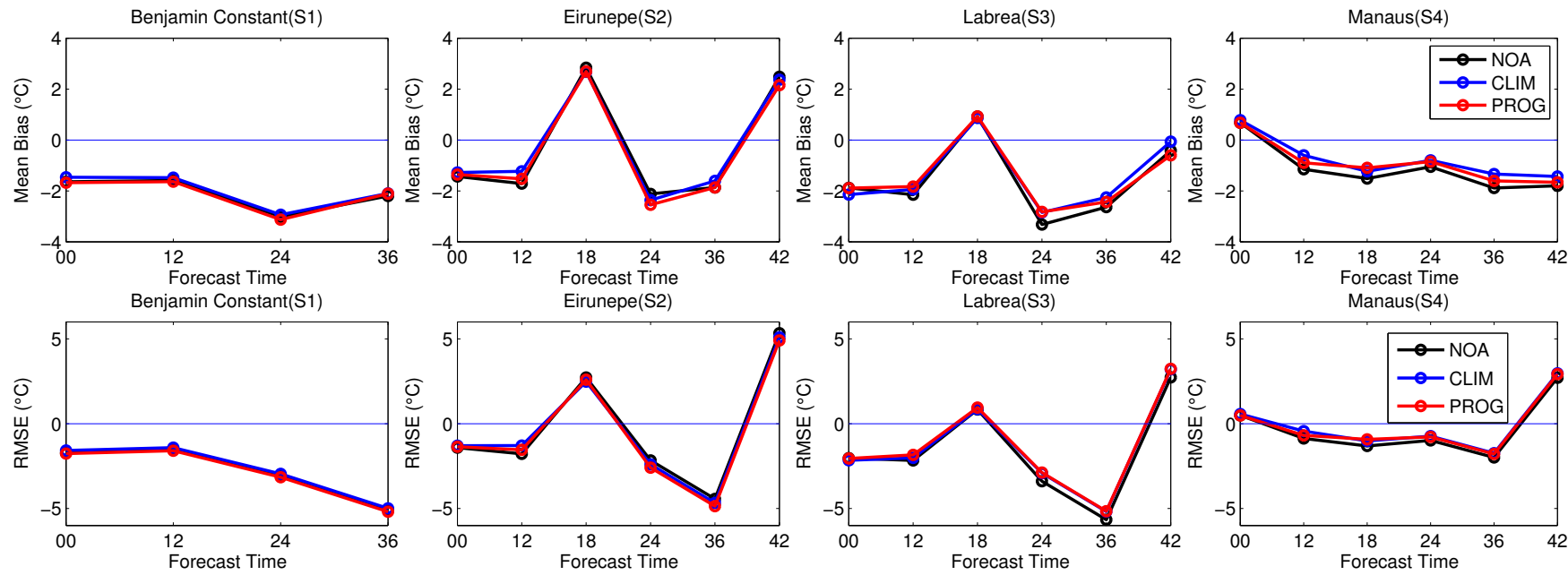

Figure 9. Mean bias and RMS error of modelled temperature at S1, S2, S3 and S4 locations (Fig. 1), averaged over the whole period.
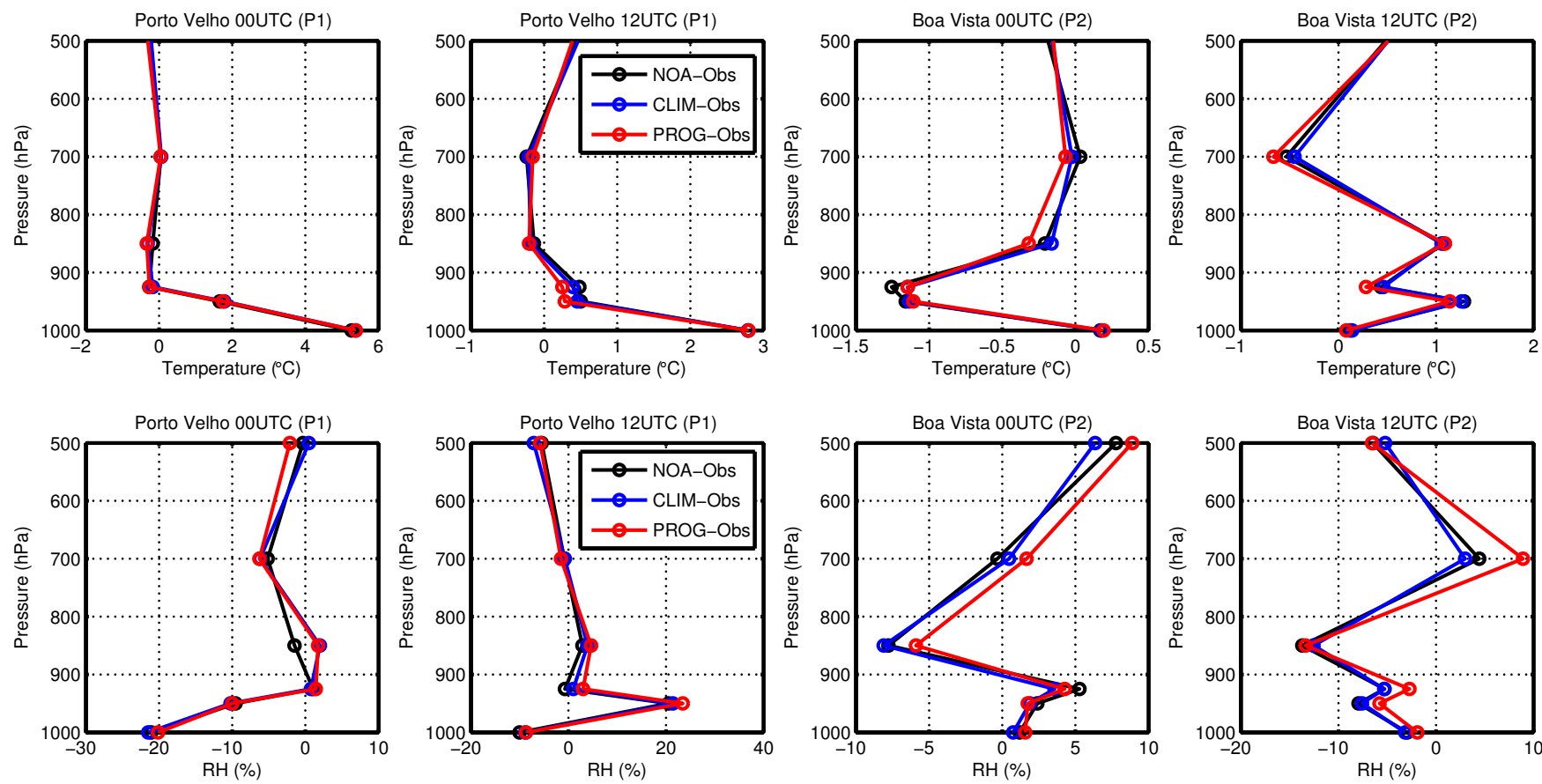

Figure 10. Profiles of modelled minus observed temperature and relative humidities from radiosondes at P1 and P2 (locations shown in Fig. 1).

impact on clouds and convection. Figure 11a shows the mean precipitation rate averaged over the whole campaign for the NOA simulation. There are large local differences in mean rainfall between the three simulations (NOA, PROG, CLIM) (Fig. 11b and c) mainly due to changes in the location of precipitation events. When smoothed over a $150 \mathrm{~km}$ grid these changes are still around $4 \mathrm{mmday}^{-1}$, although the change in the regional mean is small: for Box A (Fig. 11a), BBA in PROG or CLIM reduces rain by around $0.055 \mathrm{~mm} \mathrm{day}^{-1}$ compared with NOA (mean rainfall is $1.2 \mathrm{~mm}^{-1} \mathrm{yy}^{-1}$ ). Pre- cipitation reductions of $\sim 5 \%$ found in this study are therefore slightly greater than the Tosca et al. (2013) study which shows a $(2 \%)$ decrease over Amazonia.

Changes in the Probability distribution function (PDF) of rainfall over Box A are shown in Fig. 11d and e, with absolute changes in the pdf shown in grey and fractional changes in blue. For both PROG and CLIM, BBA tends to increase the frequency of both no rainfall and the highest rainfall rates, while decreasing moderate rainfall rates. A KolmogorovSmirnov test conducted for the samples showed that the 

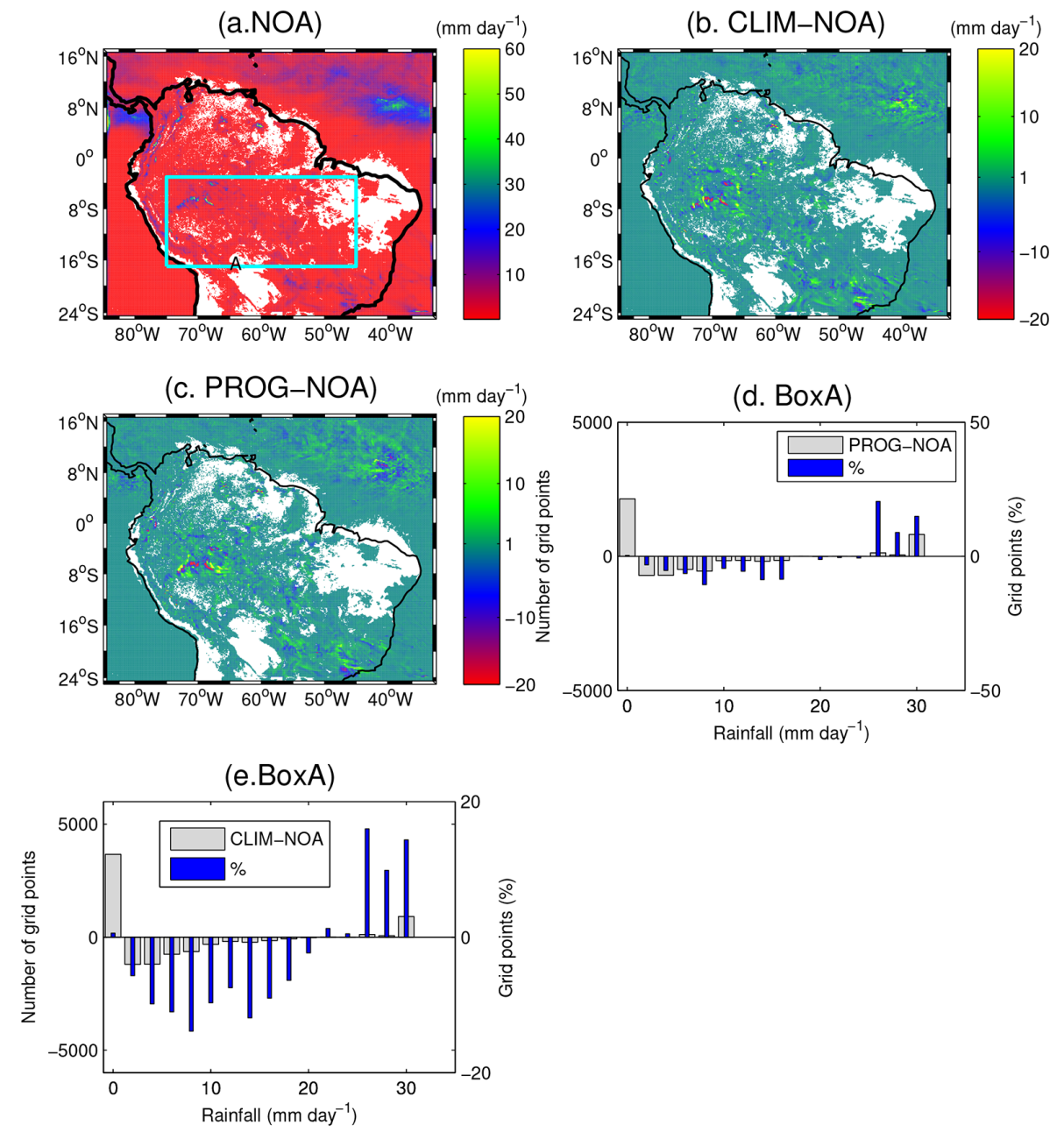

Figure 11. The whole SAMBBA period mean rainfall (a) and differences in rainfall (b, c); white region shows masked 0 values (a, b, c) and changes to frequency distributions of precipitation (d-e) from BBA to NOA for box A. Blue bars are in percentage with respect to differences.

results are statistically significant at $98 \%$ confidence level. This effect on rain rates may be linked to BBA increasing stability in the lower atmosphere due to reduced net surface flux and increased radiative warming of the atmosphere.

To further explore the mechanisms for simulated changes in rainfall we calculated the water budget over Box A for all model simulations on day 1 and day 2 . BBA reduces the net radiation, which causes a decrease in surface evapotranspiration $\left(0.2\right.$ and $0.3 \mathrm{mmday}^{-1}$ in PROG and CLIM, a 5 and $6 \%$ decrease respectively; Table 2). The radiative heating from the BBA enhances the stability of the atmosphere generally reduces precipitation by 0.05 to $0.12 \mathrm{~mm} \mathrm{day}^{-1}$ except in day 2 of PROG, which shows a small $\left(0.02 \mathrm{~mm} \mathrm{day}^{-1}\right)$ increase. The change in water vapour convergence into box $\mathrm{A}$ is unclear, with small increases and decreases in PROG and CLIM for days 1 and $2\left(-0.02\right.$ to $\left.+0.1 \mathrm{~mm} \mathrm{day}^{-1}\right)$. The overall consequence is that the change in water budget of box A from BBA is dominated by the reduction in surface evapotranspiration resulting from the decreased net surface radiation. Therefore, the overall net effect of BBA is a drying of the atmosphere in the Amazonian region largely due to reduced latent heat fluxes. The drying of the atmosphere due to BBA will be further investigated in future studies using the UKCA model, including indirect radiative effects.

\section{Summary and conclusions}

A limited area version of the MetUM is used to investigate direct radiative effects of BBA over tropical South America during the end of the dry season (the SAMBBA period of 14 September to 3 October 2012) and impacts on the atmosphere and short-range weather forecasts. Three simulations were conducted with different aerosols representations: (i) no aerosols (NOA), (ii) monthly mean climatology BBA (CLIM) and (iii) BBA modelled prognostically with the CLASSIC aerosol scheme (PROG). Impacts are quantified 
from the first 2 days of forecasts initialised from meteorological analyses.

The modelled BBA reduced clear-sky net radiation at the TOA by $8 \mathrm{~W} \mathrm{~m}^{-2}$ over the region studied and reduced clearsky net radiation at the surface by on average of $15 \mathrm{~W} \mathrm{~m}^{-2}$, with direct warming of the atmosphere due to absorption of solar radiation of $7 \mathrm{~W} \mathrm{~m}^{-2}$. BBA reduced cloud cover and all-sky radiative effects were lower than clear-sky effects: -4 and $-9 \mathrm{~W} \mathrm{~m}^{-2}$ for the TOA and surface net radiative effects respectively. The reduced net surface radiation from BBA cooled the mean $2 \mathrm{~m}$ air temperature by on average $0.1^{\circ} \mathrm{C}$. The temperature changes found here are less than the $\sim-0.3^{\circ} \mathrm{C}$ changes found by Wu et al. (2011) using WRFChem model over the South America during the dry period of September 2011. This difference in results is consistent with the higher AODs in the Wu et al. (2011) study. We also expect BBA impacts to be greater in a more representative biomass burning year as the 2012 biomass burning season had lower than average AOD values.

The BBA cools the lower BL by around $0.2^{\circ} \mathrm{C}$ but heats the atmosphere above by up to $0.2^{\circ} \mathrm{C}$ in the elevated BBA layer that extends to between 600 and $400 \mathrm{hPa}$. The cooling of the $\mathrm{BL}$ is consistent with the BBA reducing surface sensible heat fluxes. This reduces BL growth and results in a decrease in the mean BL depth by around $19 \mathrm{~m}$. The BBA induces a weak $\left(0.2 \mathrm{~m} \mathrm{~s}^{-1}\right)$ cyclonic circulation in the lower BL, with a weak anticyclonic circulation above (up to $0.6 \mathrm{~m} \mathrm{~s}^{-1}$ ) due to the horizontal gradients in BBA heating. Effects of BBA are communicated to the upper troposphere due to changes in uplift and subsidence affecting mean upper tropospheric temperatures by up to $+0.2{ }^{\circ} \mathrm{C}$.

The evaluation against observations shows that the model simulations that included aerosols gave a better representation of near-surface air temperature and relative humidity than models without aerosols (mean correlation of 0.79 and 0.72 in NOA compared to 0.83 and 0.79 in PROG for nearsurface air temperature and RH respectively with $99 \%$ significant confidence level). However, the improvements were small compared with model error. The difference in results between simulations with a climatological and prognostic representation of aerosols were even smaller and statistically insignificant. Similarly, comparisons with radiosondes show negligible differences from including BBA compared with model error. These results suggest that while inclusion of a realistic representation of BBA has impacts on the model radiation fields, improvements on the mean forecast skill are small at the 2-day forecast lead times analysed in this study. This is most likely due to the strong constraint of the 3D-VAR data assimilation at short forecast lead times. Indeed impacts on the meteorology on day 2 of the forecast were larger than on day 1 (Table 2), indicating that prognostic BBA might have larger impacts on longer medium-toseasonal-range weather forecast and on climate simulations. Future studies within SAMBBA will investigate this using individual case studies from the SAMBBA period.
The inclusion of a prognostic BBA scheme gives a superior aerosol forecast compared to an aerosol climatology but in this study did not improve the mean model skill for temperature and relative humidity significantly over that of the BBA climatology. This reiterates the findings of Mulcahy et al. (2014) that the inclusion of realistic aerosol-radiative interactions are of key importance in operational NWP forecasting systems but that in many cases a monthly varying speciated aerosol climatology can provide sufficient skill. However, given the highly variable nature of $\mathrm{BB}$ emissions the more advanced fully prognostic treatment of BBA is required in order to provide an accurate aerosol prediction capability.

In this study PROG and CLIM BBA tended to reduce mean precipitation by around $5 \%\left(0.06 \mathrm{mmday}^{-1}\right.$; Table 2), although PROG gave a small increase on day 2 $\left(0.02 \mathrm{~mm} \mathrm{day}^{-1}\right)$. It can be speculated that such reductions may lead to more biomass burning over Amazonia (Aragao et al., 2014). However, it should be noted that aerosolcloud feedbacks on cloud brightness, lifetime and precipitation efficiency, which may alter the sensitivity of precipitation to BBA, were not modelled in this study. The BBA also led to changes in the location of convection, resulting in localised changes in precipitation of around $4 \mathrm{mmday}^{-1}$, when smoothed on a $150 \mathrm{~km}$ scale. Furthermore, the BBA decreased the frequency of moderate rain rates and increased the frequency of both no rain and high rain rates. These changes in the distribution of rainfall intensity may be linked to the stabilisation of the lower atmosphere by BBA through the direct radiative effects.

The water vapour budget analysis over the Amazonian region reveals that by reducing the net surface radiation, the BBA reduces surface latent heat fluxes by $0.2 \mathrm{mmday}^{-1}$. There is a drying of the atmosphere as this reduction in latent heat fluxes is not compensated by the reduced precipitation (around $-0.06 \mathrm{~mm} \mathrm{day}^{-1}$ ) or increased water vapour convergence $\left(-0.02\right.$ to $\left.+0.1 \mathrm{~mm} \mathrm{day}^{-1}\right)$. Such impacts of BBA on the water budget of Amazonia will be investigated in future SAMBBA modelling studies using longer simulations that are more free to evolve away from their initial state.

Acknowledgements. The MODIS data used in this study were produced with the Giovanni online data system, developed and maintained by the National Aeronautics and Space Administration (NASA) GES DISC. We acknowledge the MODIS teams for the data used. We thank Jim Haywood for a careful reading and discussion of the manuscript. We thank the principal investigators and their staff for establishing and maintaining the eight AERONET sites used in this investigation. The Facility for Airborne Atmospheric Measurement (FAAM) BAe-146 Atmospheric Research Aircraft is jointly funded by the Met Office and Natural Environment Research Council (NERC) and operated by DirectFlight Ltd. We would like to acknowledge the dedicated efforts of FAAM, DirectFlight, the National Institute for Space Research (INPE), University of Sao Paulo and the Brazilian Ministry of Science and 
Technology for making the SAMBBA measurement campaign possible. We thank Joel Brito from the University of Sao Paulo for providing surface observation over Amazonas. The SAMBBA project was funded by the Met Office and NERC with grant number NE/J009822/1. We acknowledge use of the MONSooN system, a collaborative facility supplied under the Joint Weather and Climate Research Programme, which is a strategic partnership between the Met Office and NERC. We thank the three anonymous reviewers and editor for their comments on our manuscript.

Edited by: G. Myhre

\section{References}

Andreae, M. and Rosenfeld, D.: Aerosol-cloud-precipitation interactions. Part 1. The nature and sources of cloud-active aerosols, Earth-Sci. Rev., 89, 13-41, 2008.

Aragao, L. E., Poulter, B., Barlow, J. B., Anderson, L. O., Malhi, Y., Saatchi, S., Phillips, O. L., and Gloor, E.: Environmental change and the carbon balance of Amazonian forests, Biol. Rev., 89, 913-931, 2014.

Archer-Nicholls, S., Lowe, D., Schultz, D. M., and McFiggans, G.: Aerosol-radiation-cloud interactions in a regional coupled model: the effects of convective parameterisation and resolution, Atmos. Chem. Phys. Discuss., 15, 27449-27499, doi:10.5194/acpd-15-27449-2015, 2015.

Artaxo, P., Rizzo, L. V., Brito, J. F., Barbosa, H. M., Arana, A., Sena, E. T., Cirino, G. G., Bastos, W., Martin, S. T., and Andreae, M. O.: Atmospheric aerosols in Amazonia and land use change: from natural biogenic to biomass burning conditions, Faraday Discuss., 165, 203-235, 2013.

Bellouin, N., Rae, J., Jones, A., Johnson, C., Haywood, J., and Boucher, O.: Aerosol forcing in the Climate Model Intercomparison Project (CMIP5) simulations by HadGEM2-ES and the role of ammonium nitrate, J. Geophys. Res.-Atmos., 116, D20206, doi:10.1029/2011JD016074, 2011.

Bence, J. R.: Analysis of short time series: correcting for autocorrelation, Ecology, 76, 628-639, doi:10.2307/1941218, 1995.

Bowman, D. M. J. S., Balch, J. K., Artaxo, P., Bond, W. J., Carlson, J. M., Cochrane, M. A., D’Antonio, C. M., DeFries, R. S., Doyle, J. C., Harrison, S. P., Johnston, F. H., Keeley, J. E., Krawchuk, M. A., Kull, C. A., Marston, J. B., Moritz, M. A., Prentice, I. C., Roos, C. I., Scott, A. C., Swetnam, T. W., van der Werf, G. R., and Pyne, S. J.: Fire in the Earth system, Science, 324, 481-484, 2009.

Brito, J., Rizzo, L. V., Morgan, W. T., Coe, H., Johnson, B., Haywood, J., Longo, K., Freitas, S., Andreae, M. O., and Artaxo, P.: Ground-based aerosol characterization during the South American Biomass Burning Analysis (SAMBBA) field experiment, Atmos. Chem. Phys., 14, 12069-12083, doi:10.5194/acp-1412069-2014, 2014.

Brown, A., Beare, R., Edwards, J., Lock, A., Keogh, S., Milton, S., and Walters, D.: Upgrades to the boundary-layer scheme in the Met Office numerical weather prediction model, Bound.-Lay. Meteorol., 128, 117-132, 2008.

Chen, D., Liu, Z., Schwartz, C. S., Lin, H.-C., Cetola, J. D., Gu, Y., and Xue, L.: The impact of aerosol optical depth assimilation on aerosol forecasts and radiative effects during a wild fire event over the United States, Geosci. Model Dev., 7, 2709-2715, doi:10.5194/gmd-7-2709-2014, 2014.

Collins, W. J., Bellouin, N., Doutriaux-Boucher, M., Gedney, N., Halloran, P., Hinton, T., Hughes, J., Jones, C. D., Joshi, M., Liddicoat, S., Martin, G., O'Connor, F., Rae, J., Senior, C., Sitch, S., Totterdell, I., Wiltshire, A., and Woodward, S.: Development and evaluation of an Earth-System model - HadGEM2, Geosci. Model Dev., 4, 1051-1075, doi:10.5194/gmd-4-10512011, 2011.

Cook, J. and Highwood, E.: Climate response to tropospheric absorbing aerosols in an intermediate general-circulation model, Q. J. Roy. Meteorol. Soc., 130, 175-191, 2004.

Crutzen, P. J. and Andreae, M. O.: Biomass burning in the tropics: Impact on atmospheric chemistry and biogeochemical cycles, Science, 250, 1669-1678, 1990.

Crutzen, P. J. and Zimmermann, P. H.: The changing photochemistry of the troposphere, Tellus B, 43, 136-151, 1991.

Darbyshire, E. and Johnson, B.: The South American Biomass Burning Analysis (SAMBBA) Field Experiment, SeptemberOctober 2012, Brazil: Summary of Research Flights, The University of Manchester and the Met Office, available on request from the authors, 1-180, 2013.

Davies, T., Cullen, M., Malcolm, A., Mawson, M., Staniforth, A., White, A., and Wood, N.: A new dynamical core for the Met Office's global and regional modelling of the atmosphere, Q. J. Roy. Meteorol. Soc., 131, 1759-1782, 2005.

Edwards, J. and Slingo, A.: Studies with a flexible new radiation code. I: Choosing a configuration for a large-scale model, Q. J. Roy. Meteorol. Soc., 122, 689-719, 1996.

Gregory, D. and Rowntree, P.: A mass flux convection scheme with representation of cloud ensemble characteristics and stabilitydependent closure, Mon. Weather Rev., 118, 1483-1506, 1990.

Haywood, J. and Boucher, O.: Estimates of the direct and indirect radiative forcing due to tropospheric aerosols: a review, Rev. Geophys.-Richmond Virginia then Washington, 38, 513543, 2000.

Hoerger, M.: ZH: an updated version of Steiger's Z and web-based calculator for testing the statistical significance of the difference between dependent correlations, retrieved 1 March 2014, 2013.

Holben, B. N., Eck, T. F., Slutsker, I., Tanré, D., Buis, J. P., Setzer, A., Vermote, E., Reagan, J. A., Kaufman, Y. J., Nakajima, T., Lavenu, F., Jankowiak, I., and Smirnov, A.: AERONET - a federated instrument network and data archive for aerosol characterization, Remote Sens. Environ., 66, 1-16, 1998.

Ichoku, C., Remer, L. A., Kaufman, Y. J., Levy, R., Chu, D. A., Tanré, D., and Holben, B. N.: MODIS observation of aerosols and estimation of aerosol radiative forcing over southern Africa during SAFARI 2000, J. Geophys. Res.-Atmos., 108, 8499, doi:10.1029/2002JD002366, 2003.

Ichoku, C., Remer, L. A., and Eck, T. F.: Quantitative evaluation and intercomparison of morning and afternoon Moderate Resolution Imaging Spectroradiometer (MODIS) aerosol measurements from Terra and Aqua, J. Geophys. Res.-Atmos., 110, D10S03, doi:10.1029/2004JD004987, 2005.

Jacobson, M. Z.: Control of fossil-fuel particulate black carbon and organic matter, possibly the most effective method of slowing global warming, J. Geophys. Res.-Atmos., 107, 4410, doi:10.1029/2001JD001376, 2002. 
Kaiser, J. W., Heil, A., Andreae, M. O., Benedetti, A., Chubarova, N., Jones, L., Morcrette, J.-J., Razinger, M., Schultz, M. G., Suttie, M., and van der Werf, G. R.: Biomass burning emissions estimated with a global fire assimilation system based on observed fire radiative power, Biogeosciences, 9, 527-554, doi:10.5194/bg-9-527-2012, 2012.

Kaufman, Y. J. and Koren, I.: Smoke and pollution aerosol effect on cloud cover, Science, 313, 655-658, 2006.

King, M. D., Menzel, W. P., Kaufman, Y. J., Tanré, D., Gao, B.C., Platnick, S., Ackerman, S. A., Remer, L. A., Pincus, R., and Hubanks, P. A.: Cloud and aerosol properties, precipitable water, and profiles of temperature and water vapor from MODIS, IEEE T. Geosci. Remote, 41, 442-458, 2003.

Korontzi, S., Roy, D. P., Justice, C. O., and Ward, D. E.: Modeling and sensitivity analysis of fire emissions in southern Africa during SAFARI 2000, Remote Sens. Environ., 92, 376-396, 2004.

Lamarque, J.-F., Bond, T. C., Eyring, V., Granier, C., Heil, A., Klimont, Z., Lee, D., Liousse, C., Mieville, A., Owen, B., Schultz, M. G., Shindell, D., Smith, S. J., Stehfest, E., Van Aardenne, J., Cooper, O. R., Kainuma, M., Mahowald, N., McConnell, J. R., Naik, V., Riahi, K., and van Vuuren, D. P.: Historical (1850-2000) gridded anthropogenic and biomass burning emissions of reactive gases and aerosols: methodology and application, Atmos. Chem. Phys., 10, 7017-7039, doi:10.5194/acp10-7017-2010, 2010.

Lorenc, A. C., Ballard, S. P., Bell, R. S., Ingleby, N. B., Andrews, P. L. F., Barker, D. M., Bray, J. R., Clayton, A. M., Dalby, T., Li, D., Payne, T. J., and Saunders, F. W.: The Met. Office global threedimensional variational data assimilation scheme, Q. J. Roy. Meteorol. Soc., 126, 2991-3012, 2000.

Marlier, M. E., DeFries, R. S., Voulgarakis, A., Kinney, P. L., Randerson, J. T., Shindell, D. T., Chen, Y., and Faluvegi, G.: El Nino and health risks from landscape fire emissions in southeast Asia, Nat. Clim. Change, 3, 131-136, 2013.

Martin, S. T., Andreae, M. O., Artaxo, P., Baumgardner, D., Chen, Q., Goldstein, A. H., Guenther, A., Heald, C. L., Mayol-Bracero, O. L., McMurry, P. H., Pauliquevis, T., Pöschl, U., Prather, K. A., Roberts, G. C., Saleska, S. R., Silva-Dias, M. A., Spracklen, D. V., Swietlicki, E., and Trebs, I.: Sources and properties of Amazonian aerosol particles, Rev. Geophys., 48, RG2002, doi:10.1029/2008RG000280, 2010.

Mulcahy, J. P., Walters, D. N., Bellouin, N., and Milton, S. F.: Impacts of increasing the aerosol complexity in the Met Office global numerical weather prediction model, Atmos. Chem. Phys., 14, 4749-4778, doi:10.5194/acp-14-4749-2014, 2014.

Procopio, A., Artaxo, P., Kaufman, Y., Remer, L., Schafer, J., and Holben, B.: Multiyear analysis of Amazonian biomass burning smoke radiative forcing of climate, Geophys. Res. Lett., 31, L03108, doi:10.1029/2003GL018646, 2004.

Ramanathan, V., Crutzen, P., Kiehl, J., and Rosenfeld, D.: Aerosols, climate, and the hydrological cycle, Science, 294, 2119-2124, 2001

Rawlins, F., Ballard, S. P., Bovis, K. J., Clayton, A. M., Li, D., Inverarity, G. W., and Payne, T. J.: The Met Office global fourdimensional variational data assimilation scheme, Q. J. Roy. Meteorol. Soc., 133, 347-362, 2007.

Reid, J. S., Eck, T. F., Christopher, S. A., Koppmann, R., Dubovik, O., Eleuterio, D. P., Holben, B. N., Reid, E. A., and Zhang, J.: A review of biomass burning emissions part III: intensive optical properties of biomass burning particles, Atmos. Chem. Phys., 5 , 827-849, doi:10.5194/acp-5-827-2005, 2005.

Rosário, N. E., Longo, K. M., Freitas, S. R., Yamasoe, M. A., and Fonseca, R. M.: Modeling the South American regional smoke plume: aerosol optical depth variability and surface shortwave flux perturbation, Atmos. Chem. Phys., 13, 2923-2938, doi:10.5194/acp-13-2923-2013, 2013.

Rosenfeld, D., Lohmann, U., Raga, G. B., O’Dowd, C. D., Kulmala, M., Fuzzi, S., Reissell, A., and Andreae, M. O.: Flood or drought: how do aerosols affect precipitation?, Science, 321, 1309-1313, 2008.

Sena, E. T., Artaxo, P., and Correia, A. L.: Spatial variability of the direct radiative forcing of biomass burning aerosols and the effects of land use change in Amazonia, Atmos. Chem. Phys., 13, 1261-1275, doi:10.5194/acp-13-1261-2013, 2013.

Simmons, A., Uppala, S., Dee, D., and Kobayashi, S.: ERA-interim: new ECMWF reanalysis products from 1989 onwards, ECMWF Newsletter, 110, 25-35, 2007.

Smith, R.: A scheme for predicting layer clouds and their water content in a general circulation model, Q. J. Roy. Meteorol. Soc., 116, 435-460, 1990.

Ten Hoeve, J. E., Jacobson, M. Z., and Remer, L. A.: Comparing results from a physical model with satellite and in situ observations to determine whether biomass burning aerosols over the Amazon brighten or burn off clouds, J. Geophys. Res.-Atmos., 117, D08203, doi:10.1029/2011JD016856, 2012.

Tosca, M. G., Randerson, J. T., Zender, C. S., Flanner, M. G., and Rasch, P. J.: Do biomass burning aerosols intensify drought in equatorial Asia during El Niño?, Atmos. Chem. Phys., 10, 35153528, doi:10.5194/acp-10-3515-2010, 2010.

Tosca, M. G., Randerson, J. T., and Zender, C. S.: Global impact of smoke aerosols from landscape fires on climate and the Hadley circulation, Atmos. Chem. Phys., 13, 5227-5241, doi:10.5194/acp-13-5227-2013, 2013.

van der Werf, G. R., Randerson, J. T., Giglio, L., Collatz, G. J., Mu, M., Kasibhatla, P. S., Morton, D. C., DeFries, R. S., Jin, Y., and van Leeuwen, T. T.: Global fire emissions and the contribution of deforestation, savanna, forest, agricultural, and peat fires (19972009), Atmos. Chem. Phys., 10, 11707-11735, doi:10.5194/acp10-11707-2010, 2010.

Walters, D. N., Best, M. J., Bushell, A. C., Copsey, D., Edwards, J. M., Falloon, P. D., Harris, C. M., Lock, A. P., Manners, J. C., Morcrette, C. J., Roberts, M. J., Stratton, R. A., Webster, S., Wilkinson, J. M., Willett, M. R., Boutle, I. A., Earnshaw, P. D., Hill, P. G., MacLachlan, C., Martin, G. M., Moufouma-Okia, W., Palmer, M. D., Petch, J. C., Rooney, G. G., Scaife, A. A., and Williams, K. D.: The Met Office Unified Model Global Atmosphere 3.0/3.1 and JULES Global Land 3.0/3.1 configurations, Geosci. Model Dev., 4, 919-941, doi:10.5194/gmd-4-919-2011, 2011.

Ward, D. S., Kloster, S., Mahowald, N. M., Rogers, B. M., Randerson, J. T., and Hess, P. G.: The changing radiative forcing of fires: global model estimates for past, present and future, Atmos. Chem. Phys., 12, 10857-10886, doi:10.5194/acp12-10857-2012, 2012.

Wilson, D. R. and Ballard, S. P.: A microphysically based precipitation scheme for the UK Meteorological Office Unified Model, Q. J. Roy. Meteorol. Soc., 125, 1607-1636, 1999. 
Wu, L., Su, H., and Jiang, J. H.: Regional simulations of deep convection andbiomass burning over South America: 2. Biomass burning aerosol effects on clouds and precipitation, J. Geophys. Res.-Atmos., 116, D17209, doi:10.1029/2011JD016106, 2011.

Yu, H., Liu, S., and Dickinson, R.: Radiative effects of aerosols on the evolution of the atmospheric boundary layer, J. Geophys. Res.-Atmos., 107, 4142, doi:10.1029/2001JD000754, 2002.

Zhang, Y., Fu, R., Yu, H., Dickinson, R. E., Juarez, R. N., Chin, M., and Wang, H.: A regional climate model study of how biomass burning aerosol impacts land-atmosphere interactions over the Amazon, J. Geophys. Res.-Atmos., 113, D14S15, doi:10.1029/2007JD009449, 2008.
Zhang, Y., Fu, R., Yu, H., Qian, Y., Dickinson, R., Silva Dias, M. A. F., da Silva Dias, P. L., and Fernandes, K.: Impact of biomass burning aerosol on the monsoon circulation transition over Amazonia, Geophys. Res. Lett., 36, L10814, doi:10.1029/2009GL037180, 2009. 